УДК: 551.58

\title{
ПРОБЛЕМИ ТА ПЕРСПЕКТИВИ РОЗВИТКУ КЛІМАТОЛОГІЇ В УКРАЇНІ
}

\author{
В. О. Балабух ${ }^{1}$, канд. геогр. наук, старш. наук. співроб., \\ В. М. Хохлов ${ }^{2}$, д-р. геогр. наук, проф. \\ ${ }^{1}$ Украйнський гідрометеорологічний інститут, пр. Науки, 37, 03028, Київ, Украӥна, Balabukh@uhmi.org.ua \\ ${ }^{2}$ Одеський державний екологічний університет, вул. Львівська, 15, 65016, Одеса, Україна, khokhlovv@odeku.edu.ua \\ У статті розглядається сучасний стан кліматології в Україні, проблеми та перспективи ії \\ розвитку. Зазначено основні наукові напрямки розвитку кліматичного обслуговування в \\ країні відповідно до Глобальної рамкової основи для кліматичного обслуговування. Для \\ кожного елементу кліматичного обслуговування - платформи взаємодії з користувачами, \\ інформаційної системи кліматичного обслуговування, спостереження і моніторингу, розви- \\ тку потенціалу - виділено головні завдання для України, зазначено проблеми та запропоно- \\ вано перспективні напрямки розвитку. \\ Ключові слова: кліматологія, кліматичне обслуговування, зміна клімату.
}

\section{1. ВСТУП}

Кліматологія в Україні у своєму розвитку неодноразово проходила періоди підйому та спаду i, намагаючись давати відповіді на поставленні запитання, відкривала нові напрямки своєї діяльності. Якщо на початку свого становлення кліматологія була лише наукою про клімат, його формування, географічне районування і зміну в часі, то протягом останніх десятиріч вона перетворилась у динамічну галузь науки 3 широким набором функцій та спектром застосувань. Зростає потреба в розумінні процесів формування клімату, кліматичної системи та взаємозв'язку іiі складових, удосконаленні кліматичних прогнозів та використання кліматичної інформації для більш ефективного задоволення потреб суспільства. Значним поштовхом для цього стали зміни клімату, що носять безпрецедентний характер і вимагають прийняття відповідних заходів.

Ця стаття має на меті огляд сучасного стану кліматології в Україні та визначення головних елементів кліматичного обслуговування - галузі, яка спрямована, зокрема, на наукове забезпечення економіки рішеннями для подолання наслідків змін клімату.

\section{2. ДЕРЖАВНА ПОЛІТИКА ЩОДО ЗМІН КЛІМАТУ В УКРАЇНІ НА СУЧАСНОМУ ЕТАП - РОЛЬ КЛІМАТОЛОГІї}

На всесвітньому економічному форумі в Давосі у січні 2017 року експерти визначили 30 глобальних ризиків, що впливають на стабільний розвиток людства, а також 13 тенденцій, які можуть посилити їх або змінити співвідношення між ними [1].

До трійки найбільш впливових ризиків, що визначали глобальний розвиток 32013 по
2017 рр., потрапили екстремальні погодні явища та масштабні стихійні лиха. Вони ж увійшли до п'ятірки найбільш ймовірних ризиків за цей період. Зміни клімату були також серед трьох тенденцій, що визначають глобальний розвиток i можуть посилити глобальні ризики. Вони створюють серйозні загрози та виклики для сталого розвитку суспільства, спричинені підвищенням ризиків для здоров'я та життєдіяльності людини, природних екосистем, секторів економіки і потребують детального дослідження та розробки заходів з адаптації.

У Рамковій Конвенції ООН зі зміни клімату, прийнятій у Парижі в 2015 р., зазначено, що глобальною метою адаптації є укріплення адаптаційних можливостей, підвищення опірності і зменшення вразливості до зміни клімату з метою сприяння стійкого розвитку суспільства. Важливим завданням адаптації $\epsilon$ попередження та мінімізація втрат і збитків, пов'язаних 3 негативними змінами кліматичної системи.

Ратифікація Україною Паризької угоди та подальша імплементація іiї положень потребує науково обгрунтованої інформації щодо фактичних і очікуваних змін клімату та їх наслідків, визначення ризиків та вразливості до зміни клімату на рівні регіонів, областей, територіальних громад, секторів економіки. Прийняття управлінських рішень щодо забезпечення запобігання зміні клімату та адаптації до неї потребує обізнаності громадянського суспільства та органів державної влади з усіма аспектами проблеми зміни клімату. Для цього необхідно мати комплексну характеристику стану, фактичних та очікуваних змін клімату в регіонах України.

Хоча підписання Україною Паризької угоди є визначним кроком для розвитку сучасної кліматології, державна політика України у сфері зміни 
клімату має фрагментарний характер і до теперішнього часу розглядається виключно як складова екологічної політики. Відсутність системного підходу до проблеми зміни клімату в цілому унеможливлює прийняття управлінських рішень щодо дій із запобігання зміні клімату та адаптації до неї в масштабах всієї економіки держави. У той же час, нові завдання, які обумовлені доцільністю ратифікації Україною Паризької угоди та подальшої імплементації іiі положень, потребують формування цілісної і послідовної державної політики у сфері зміни клімату.

Основні причини виникнення проблеми щодо невідкладного вдосконалення зазначеної державної політики, яка потребує розв'язання, $є$ такими [2]:

- недостатня законодавча та нормативно-правова урегульованість її основних засад;

- низька інституційна спроможність та слабка координація органів державної влади щодо планування і реалізації дій у зазначеній сфері;

- неузгодженість політики у сфері зміни клімату з законодавчими та нормативно-правовими актами в інших соціально-економічних сферах;

- недостатність фінансових ресурсів;

- відсутність системного підходу до створення наукового підгрунтя діяльності у сфері зміни клімату;

- недостатня обізнаність громадянського суспільства та органів державної влади з усіх аспектів проблеми зміни клімату та низьковуглецевого розвитку держави.

Політично, економічно і науково обгрунтовані рішення 3 питань зміни клімату мають прийматися для всіх секторів економіки.

Тому предметом сучасної кліматології $\epsilon$ вивчення процесів формування клімату, кліматичної системи та взаємозв'язку між її складовими, діагноз сучасної мінливості та змін клімату, вивчення кліматично обумовлених ресурсів та їх впливу на життєдіяльність населення, прогноз стану клімату в майбутньому. При цьому теоретична кліматологія спрямована на вивчення фізики формування глобального клімату і механізмів його змін, а прикладна вивчає вплив клімату та його змін на стан навколишнього середовища, екологію, економіку.

Виходячи 3 цього, у сучасні кліматології головними напрямками пов'язаних зі зміною клімату досліджень $\epsilon$ :

- дослідження клімату Землі в минулому і у теперішній час, включаючи його природну мінливість, причини коливань і змін, передбачуваність кліматичної системи, екстремальні кліма- тичні явища, питання як і наскільки змінився клімат і чи являються ці зміни значимими;

- уточнення кількісних оцінок факторів, що визначають зміни клімату;

- зменшення невизначеностей оцінок змін клімату у майбутньому, розвиток національних кліматичних моделей і більш широке їх використання в фундаментальних і прикладних дослідженнях. При цьому розробка саме національних кліматичних моделей належить до найвищих пріоритетів кліматології, оскільки без власних моделей і відповідної інфраструктури, яка забезпечує їх належний розвиток, держава не може мати незалежну, науково обгрунтовану позицію при виробленні тих чи інших політичних і економічних рішень;

- дослідження чутливості та здатності до адаптації екосистем і економічного сектора до змін клімату; визначення та оцінка можливостей адаптації;

- вивчення можливостей управління ризиками, наукове забезпечення управління діями щодо адаптації та планування, пов'язаних з впливом зміни клімату на економіку, забезпечення осіб, які приймають рішення, аналітичними матеріалами та оцінками наслідків прийняття тих чи інших заходів з адаптації.

Останній напрямок кліматологічних досліджень утворився тільки протягом останніх декількох років. У суспільства виникає потреба краще управляти ризиками i можливостями, що мають місце в результаті мінливості і зміни клімату; особливо це стосується тих, хто є найбільш вразливий до небезпечних кліматичних явищ. Вирішення цієї проблеми стало головною метою Глобальної рамкової основи для кліматичного обслуговування, прийнятої Всесвітньою Метеорологічною організацією у жовтні 2012 та Плану іiї реалізації у 2014 році $[3,4]$.

\section{3. КЛІМАТИЧНЕ ОБСЛУГОВУВАННЯ}

Головним завданням кліматичного обслуговування i, відповідно, прикладної кліматології у теперішній час $\epsilon$ наукове та інформаційноаналітичне забезпечення адаптації економіки і населення країни до поточного i очікуваного стану кліматичної системи [3].

Реалізовуватиметься Рамкова основа за допомогою підготовки і включення науково обгрунтованої кліматичної інформації та прогнозів у планування, політику і практику.

Розвиток кліматичного обслуговування, відповідно до прийнятої Рамкової основи та Плану його реалізації, повинен сприяти зменшенню 
вразливості суспільства до небезпечних явищ погоди шляхом більш ефективного надання кліматичної інформації, активізації іiі використання в процесі прийняття рішень, посиленні взаємодії постачальників і користувачів кліматичного обслуговування, отриманні максимальної користі від використання існуючої інфраструктури кліматичного обслуговування. Для цього Глобальна Рамкова основа передбачає забезпечити перетворення кліматичної інформації в кліматичну продукцію.

Для ефективного кліматичного обслуговування, відповідно до Рамкової основи [3], необхідно п'ять основних елементів (рис. 1): платформа взаємодії з користувачами, інформаційна система кліматичного обслуговування, спостереження і моніторинг, розвиток потенціалу. Взаємодія 3 користувачами $є$ ключовим фактором кліматичного обслуговування для усіх елементів.

Відповідно до Рамкової основи необхідно, насамперед, займатися розробкою і забезпеченням кліматичного обслуговування у тих областях, де вирішуються проблеми першорядного значення для умов життя людей і які надають найшвидші можливості для підвищення рівня безпеки та поліпшення добробуту людини. До цих пріоритетних галузей належать сільське господарство та продовольча безпека, зменшення небезпеки стихійних явищ, охорона здоров'я i водні ресурси. В Україні до цього списку варто було б долучити й енергетику та в перспективі транспорт і будівництво.

Розглянемо докладніше складові кліматичного обслуговування. Платформа взаємодії 3 користувачами (рис. 1) - це механізм, що забезпечує взаємодію між користувачами, науковцями i постачальниками кліматичної інформації на всіх рівнях [3]. Він сприяє ефективному процесові ухвалення рішень 3 урахуванням кліматичної інформації.

На даний час в Україні такий механізм відсутній. Частково взаємодія між користувачами, постачальниками кліматичної інформації та науковцями здійснюється шляхом виконання науково-дослідних робіт, у Робочих групах певної направленості (наприклад, Робоча група зі зниження ризику паводків та адаптації до зміни клімату в басейні Дністра), міжвідомчих цільових групах (Міжвідомча комісію із забезпечення виконання Рамкової конвенції ООН про зміну клімату та ін.) на семінарах, круглих столах, конференціях і потребує суттєвого удосконалення та координації. Для подальшого розвитку

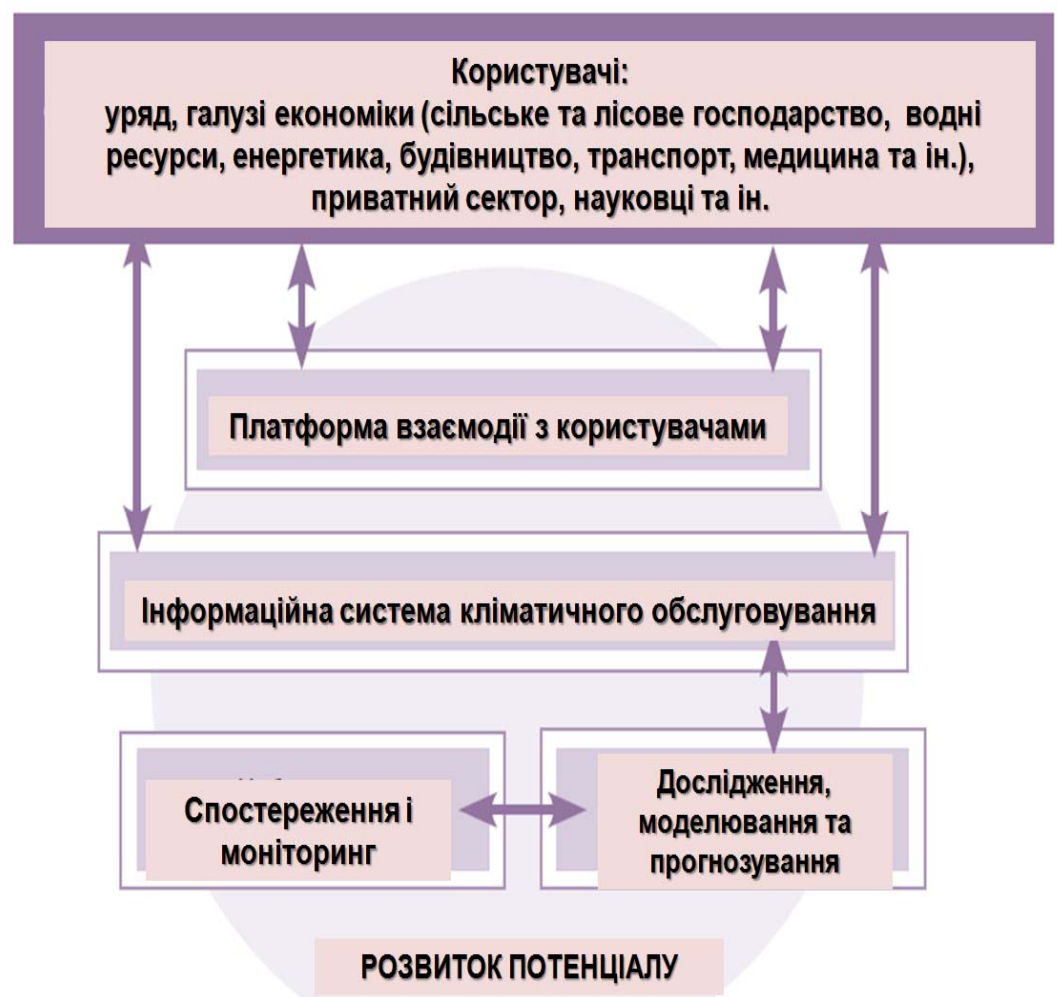

Рис. 1 - Основні елементи Глобальної Рамкової основи для кліматичного обслуговування [3]. 
кліматичного обслуговування потрібно розробити механізм взаємозв'язку з користувачами, у якому необхідно передбачити набагато вищий рівень їх участі в усіх аспектах проведення гідрометеорологічних спостережень, надання та використання кліматичної інформації.

Другим елементом кліматичного обслуговування $\epsilon$ інформаційна система кліматичного обслуговування (рис. 1) - механізм, за допомогою якого інформація про клімат регулярно збирається, зберігається і обробляється для підготовки кліматичної продукції [3]. Цей механізм передбачає Розвиток технології збору, обробки та поширення інформації, Розвиток інформаційно-аналітичних технологій та геоінформаційних систем.

Існуюча в Україні система збору та обробки гідрометеорологічної інформації має ряд недоліків:

- оснащення мережі найбільш масових спостережень застарілими вимірювальними приладами, які не мають пристроїв автоматичного занесення результатів вимірювань параметрів стану природного середовища на технічні носії і введення в канали телеграфної або супутникового зв'язку;

- ручна зйомка великих обсягів даних вимірювань і спостережень до книжок 3 подальшим ручним введенням їх в канали теле- і радіозв'язку, пересилання книжок і таблиць до Центральної геофізичної обсерваторії різко уповільнює процес збору даних і є джерелом значної кількості помилок;

- використання різного програмного забезпечення підсистем обробки режимної інформації у різних гідрометеорологічних установах, які не об'єднані в єдиний технологічний комплекс. Це призводить до дублювання типових операцій, отримання різних результатів обчислень та нераціонального використання людських і матеріальних ресурсів;

- недостатнє оснащення сучасною обчислювальною технікою та недостатність ліцензійного програмного забезпечення;

- застарілі прилади, велика частка рутинного ручної праці, слабкий зворотний зв'язок, недолік та/або обмежені можливості обчислювальної техніки не дозволяють кардинально вирішити основні проблеми ні власне обробки режимної інформації, ні забезпечення користувачів одержуваної в процесі іiі здійснення регламентної інформаційною продукцією на всіх рівнях системи.

Ці недоліки роблять робочі місця в установах гідрометслужби України непривабливими не тільки для висококваліфікованих фахівців, а й для випускників шкіл і коледжів.

Розвиток технологій збору, обробки та поширення інформації передбачає впровадження автоматичної системи збору оперативної інформації з мережі спостережень, контролю іiї якості, підготовку відповідної продукції та доведення іiї до користувачів.

Сучасні проблеми інформаційних технологій в гідрометеорології полягають не в нестачі інформації, а в умінні швидко іiї обробляти, аналізувати і оперативно доставити особам, які приймають рішення. Такі завдання виконують інформаційно-аналітичні системи. Основне їх призначення - забезпечення ефективної консолідації, високої агрегації даних і цілеспрямованого використання для підтримки науково-обгрунтованих рішень.

На основі інформаційно-аналітичної системи та інтегрованої бази даних поточної, прогнозної, кліматичної та соціально-економічної інформації з використанням картографічної інформації можна готувати оперативні доповіді про стан середовища і ії вплив на економіку країни, про виявлені небезпеки, загрози, негативні процеси, тенденції та проблемних ситуаціях в змінах клімату. Проте в Україні такі системи лише почали створюватись (наприклад у гідрології для прогнозу паводків) і потребують розробки для усіх пріоритетних галузей кліматичного обслуговування.

Розвиток геоінформаційних систем (ГІС) також $є$ важливим напрямком кліматології та кліматичного обслуговування, оскільки дозволяє отримувати необхідну інформацію 3 точною прив'язкою до місцевості, що є особливо важливим завданням при виявленні регіональних особливостей клімату [3]. Проте при використанні ГІС виникає низка проблем, які потребують вирішення:

- наявність правильних, 3 достатньою точністю координат пунктів спостережень;

- якість вихідних даних;

- проблеми репрезентативності даних (особливо гостро ця проблема для вітру, природної пожежної небезпеки);

- вибір методів отримання режимно-кліматичних характеристик;

- вибір чисельних методів просторової інтерполяції;

- відповідність електронних картооснов для побудови тематичних карт існуючим стандартам;

- визначення механізму вибору «правильних» 
карт по точності побудови полів і ін.

Спостереження і моніторинг (рис. 1) належить до основних елементів кліматичного обслуговування і передбачає забезпечення збору даних гідрометеорологічних спостережень, необхідних для задоволення потреб кінцевих користувачів, управління ними та їх поширення [3].

В Україні необхідна модернізації діючої системи спостережень, розширення окремих видів спостережень, відновлення і розширення пунктів гідрологічних і метеорологічних спостережень у паводко-небезпечних районах, розширення мережі метеорологічних радіолокаційних, озонометричних спостережень, базової мережі спостережень за забрудненням навколишнього природного середовища, відновлення морських рейдових, суднових експедиційних спостережень у відкритому морі. Оснащення сучасними автоматизованими та дистанційними засобами спостережень, приладами, аналітичними обладнанням, сучасними засобами зв'язку, забезпечення схоронності та збереження репрезентативності пунктів гідрометеорологічних спостережень також $€$ надзвичайно актуальним завданням для України, без якого неможливе кліматичне обслуговування на сучасному рівні.

Четвертим елементом кліматичного обслуговування є дослідження, моделювання та прогнозування (рис. 1), які сприяють постійному підвищенню наукової цінності та ефективного використання кліматичної інформації [3].

Найбільш актуальними у цьому напрямку $\epsilon$ дослідження кліматичних ресурсів України, впливу клімату на економічну, екологічну та соціальну сферу людської діяльності та впливу людини на локальний, регіональний, глобальний клімат.

Прикладна кліматологія і кліматичне обслуговування неможливі без вивчення вразливості реципієнтів до впливів мінливості та зміни клімату в різних областях економічної і соціальної сфер і насамперед у тих галузях, що визнані найбільш пріоритетними Рамковою основою.

Розробка методології оцінки і прогнозу ризиків, які виникають під впливом метеорологічних небезпечних явищ і кліматологічних аномалій, також $\epsilon$ актуальними напрямками сучасної кліматології.

Зменшення та запобігання збиткам від небезпечних і стихійних явищ погоди потребує удосконалення та адаптації існуючих моделей і методів оцінювання та прогнозування стану атмосфери, атмосферних процесів екстремальних погодних умов та небезпечних явищ погоди.

В Україні також необхідна кардинальна пере- робка системи критеріїв небезпечності явищ погоди для запровадження їх в нормативні документи та уточнення переліку небезпечних i стихійних явищ погоди. При їх розробці необхідно керуватись принципом "Кого ми попереджаємо", що приводить до розвитку спеціалізованого обслуговування.

Пріоритетними завданнями сьогодні у сфері розвитку технологій прогнозу погоди і клімату є:

- підвищення деталізації і розвиток фізичного наповнення моделей;

- розвиток технологій ансамблевого прогно3y;

- розробка системи засвоєння даних, здатної ефективно засвоювати різнорідні дані спостережень;

- розробка методів прогнозування в імовірнісній формі;

- розвиток нових видів спеціалізованих прогнозів для забезпечення ними різних галузей економіки.

Прикладом кліматичного обслуговування в Україні, що грунтується на кліматичних прогнозах, $є$ розробка Стратегічних напрямків адаптації басейну ріки Дністер до змін клімату та Плану їхнього впровадження, розробка Плану управління басейном Дністра на національному i транскордонному рівні, що враховує вплив зміни клімату, Стратегії адаптації до зміни клімату Рахівського району Закарпаття, Кліматичної стратегії Києва, оцінка вразливості екосистем заповідних територій Полісся до зміни клімату та ін. [5-9]. Розроблені та частково впроваджені місцеві плани адаптації до змін клімату водноболотних та лісових екосистем отримали високе визнання світової екологічної спільноти.

Велика робота була зроблена науковцями Одеського державного екологічного університету, результатом якої були дві монографії [10-11], присвячені дослідженню майбутніх змін клімату і пов'язаних з ними погодних умов на різні галузі економіки України: енергетичний сектор, сільське господарство, водні та біокліматичні ресурси. Іншим вдалим прикладом є виконання проекту LAGOONS [12], в результаті чого було запропоновано найбільш ефективний план управління у найближчому майбутньому водними ресурсами Тилігульського лиману, гідроекологічні умови якого надзвичайно погіршилися в останні десятиріччя.

Проте при обслуговуванні споживачів спеціалізованою інформацією про майбутній клімат виникають проблеми, які необхідно враховувати при розробці стратегій по адаптації до зміни клімату як секторальних, так і територіальних: 
- недостатньо надійні значення деяких кліматичних характеристик (наприклад, максимальна швидкість вітру, інтенсивність опадів), завдяки тому що Україна використовує регіональні кліматичні моделі, розроблені для інших регіонів, у яких іiі територія знаходиться на межі прогнозування, де мають місце найбільші похибки;

- не завжди вдається встановити надійний зв'язок між кліматичними величинами, отриманими при моделюванні, і необхідними прикладними характеристиками;

- при вирішенні прикладних задач необхідно використовувати імовірнісні характеристики кліматичних показників, що відображають очікувані кліматичні зміни, але споживачі до цього не готові;

- у нормативні документи не включені показники, що відображають очікувані кліматичні зміни і це при тому, що мова йде про розвиток стратегічно важливих галузей.

Дуже важливим фактором для розвитку кліматичного обслуговування $є$ вартість кліматичної продукції та послуг. Для того, щоб їх визначити, необхідно розвивати і впроваджувати методи оцінки економічного ефекту від кліматичного обслуговування. У цьому напрямку необхідно:

- розробити методики оцінки ефективності використання кліматичної інформації по секторах економіки;

- оцінити вплив кліматичного обслуговування на цільові показники та індикатори діяльності погодо- та кліматозалежних галузей економіки.

Ця робота неможлива без наявності державної статистичної звітності щодо збитків від впливу небезпечних і стихійних гідрометеорологічних явищ.

Нарешті, п'ятим елементом кліматичного обслуговування Рамкової основи (рис. 1) є розвиток потенціалу, який передбачає забезпечення умов для стабільного кліматичного обслуговування, управління кліматичними ризиками: менеджмент, освіта та підготовка кадрів, створення партнерства, наукова комунікація, мобілізація ресурсів та інфраструктура та ін. [3]. В Україні $€$ базові можливості та інфраструктура у цих областях, проте вони вимагають координації і більш чіткої орієнтації на потреби користувачів.

Сучасна кліматологія - високотехнологічна галузь, що потребує відповідного матеріальнотехнічного та кадрового забезпечення. Проте їхній стан в Україні незадовільний і не дозволяє вирішити проблему підвищення ефективності кліматичного обслуговування.

Розвиток партнерства і комунікації передба- чає, насамперед, забезпечення виконання міжнародних зобов'язань та міжнародного співробітництва. Українська кліматична наука має позиціонувати себе в міжнародних програмах кліматичних досліджень 3 урахуванням національних інтересів України, використовуючи всі можливі переваги міжнародного співробітництва, у тому числі можливості фінансування власних або спільних досліджень із міжнародних джерел.

Недостатня обізнаність громадянського суспільства та органів державної влади 3 усіма аспектами зміни клімату також створює проблеми при взаємодії з користувачами і потребує фахової інформаційно пропагандистської діяльності.

Популяризація знань в області гідрометеорології, кліматології та зміни клімату передбачає підвищення обізнаності у цій галузі різних верств населення, від школярів до людей, що приймають рішення. Для цього необхідно використовувати не лише традиційні форми роботи такі як семінари, круглі столи, конференції, а й нові форми, використовуючи нові можливості, та враховувати категорії населення. Так, УкрГМІ ДСНС та НАН України разом з фондом «Відкрита політика» та Французьким інститутом і за підтримки Посольства Франції в Україні до COP21 провели інформаційну кампанію, яка являла собою цикл регулярних щотижневих прес-конференцій у Національній агенції «Укрінформ». Проведений співробітниками УкрГМІ науковий еко-уікенд для всієї родини «Глобальні зміни клімату та їх регіональні прояви в Україні» дозволив його учасникам більше дізнатись про метеорологію і гідрологію, клімат і погоду, тенденції та проблеми в галузі, поспілкуватись 3 провідними фахівцями у цих областях, а на науковому пікніку всі бажаючі могли познайомитись із «Майстернею прогнозу погоди і клімату». Співробітники Одеського державного екологічного університету під час виконання двох міжнародних наукових проектів OrientGate (http://www.orientgateproject.org/) та Black Sea HotSpots (http://bs-hotspots.eu/) брали участь у проведенні серії семінарів із нарощування потенціалу, щодо зниження ризику надзвичайних ситуацій та кліматичної адаптації та створенні веб-платформи даних із комплектом вебінструментів, які забезпечують доступ до даних кліматичних спостережень і моделювань будьяких зацікавлених осіб та осіб, що визначають політику.

Важливим напрямком популяризації знань в області гідрометеорології може бути активна робота в соціальних мережах, проте ії необхідно проводити не фрагментарно, а систематично i 
для цього передбачати відповідні матеріальні і людські ресурси. Ефективна популяризація знань в області гідрометеорології, кліматології та зміни клімату потребує фахової науковопопулярної літератури про складові кліматичної системи їх зміни та наслідки, яка стосується проблем в Україні.

\section{4. ВИСНОВКИ}

Таким чином, аналіз стану кліматології як науки в Україні протягом останніх років свідчить про невідповідність між зростаючими вимогами суспільства до обсягів та якості продукції, що надає гідрометеорологічна служба України, та іiі реальними можливостями задовольнити ці вимоги у зв'язку з прогресуючим відставанням науково-технічної бази від вимог сьогодення, що потребує екстраординарних заходів підтримки іiі наукового потенціалу.

Успішний розвиток кліматології, ефективного кліматичного обслуговування в Україні та імплементація положень Паризької угоди потребують формування цілісної і послідовної державної політики у сфері зміни клімату, якій сприятиме прийнята Кабінетом Міністрів України у грудні 2016 р. Концепція реалізації державної політики у сфері зміни клімату на період до 2030 p. Наступним кроком має стати затвердження Кліматичної доктрини України та розробка Кліматичної програми, що містила б скоординований план наукових досліджень, прогнозування загроз національній безпеці, ефективні рекомендації щодо адаптації галузей економіки та суспільства до мінливості та зміни клімату.

\section{СПИСОК ЛІТЕРАТУРИ}

1. The Global Risks.Report 2017. World Economic Forum, Geneva. 2017. 78 p. World Economic Forum. http://www3.weforum.org/docs/GRR17_Report_web.pdf

2. Розпорядження Кабінету Міністрів України "Про схвалення Концепції реалізації державної політики у сфері зміни клімату на період до 2030 року” № 932-р редакція від 07.12.2016 // Урядовий портал. http://www.kmu.gov.ua/control/uk/cardnpd?docid=249573705

3. Знания о климате как основа для действия: Глобальная рамочная основа для климатического обслуживания укрепление возможностей развивающихся стран // BMO. 2011. № 1065. 293 c. http://www.uncclearn.org/ sites/default/files/inventory/wmo01_5_0.pdf

4. План осуществления Глобальной Рамочной основы для климатического обслуживания // ВМО. 2014. 96 с. https://www.wmo.int/gfcs/sites/default/files/implementationplan//GFCS-IMPLEMENTATION-PLAN-14211_ru.pdf

5. Стратегические направления адаптации к изменению климата в бассейне Днестра // UNECE. 2015. 72 с. https://ehlm.unece.org/pages/viewpage. action?pageId=22741054

6. План внедрения стратегических направлений адаптации к изменению климата в бассейне Днестра // Zoї Envi- ronment Network. 2017. $76 \mathrm{c}$. http://www.zoinet.org/web/ sites/default/files/publications/Dniester-web.pdf

7. Адаптація до зміни клімату: навчальний посібник / П. Штясний, М. Лапін, В. Балабух; Карпатський Інститут Розвитку; Агентство сприяння сталому розвитку Карпатського регіону «ФОРЗА». 2015. 88 с. http://www.forza.org.ua/sites/default/files/global_climate_changes training_manual_ua_screen_final.pdf

8. Київська міська стратегія. Попередження та адаптація до зміни клімату: проект / Київський національний університет імені Тараса Шевченка. 2013. 188 с.

9. Вразливі екосистеми Поліського природного заповідника та його околиць в умовах глобального потепління: проблеми та шляхи вирішення / Балабух В. О., Жила С. М., Орлов О. О., Яремченко О. А. Київ: Вид-во ТОВ «НВП Інтерсервіс», 2013. $92 \mathrm{c}$.

10. Оцінка впливу кліматичних змін на галузі економіки України / під ред. С. М. Степаненко, А. М. Польового. -Одеса: Екологія, 2011. 694 с.

11. Кліматичні зміни та їх вплив на сфери економіки України / під ред. С. М. Степаненко, А. М. Польового. Одеса: «ТЕС», 2015. $518 \mathrm{c}$.

12. Coastal Lagoons in Europe. Integrated Water Resource Management. London: IWA Publishing, 2015. 227p. (Eds: Ana I. Lillebø, Per Stålnacke, Geoffrey D. Gooch).

\section{REFERENCES}

1. The Global Risks.Report 2017. World Economic Forum, Geneva. 2017. 78 p. World Economic Forum. http://www3.weforum.org/docs/GRR17_Report_web.pdf

2. Order of the Cabinet of Ministers of Ukraine of December 7, 2016 No. 932-r "About approval of the Concept of sale of state policy in the sphere of climate change for the period till 2030". Government portal. http://www.kmu.gov.ua/control/uk/ cardnpd?docid=249573705 (In Ukrainian).

3. Climate knowledge for action: a global framework for climate services - Empowering the most vulnerable. World Meteorological Organization, 2011, no. 1065. 293 p. http://www.uncclearn.org/sites/default/files/inventory/ wmo01_5_0.pdf(In Russian)

4. Implementation Plan for the Global Framework for Climate Services. World Meteorological Organization, 2014. 96 p. https://www.wmo.int/gfcs/sites/default/files/implementationplan//GFCS-IMPLEMENTATION-PLAN-4211_ru.pdf (In Russian)

5. Strategic framework for adaptation to climate change in the Dniester River Basin. UNECE, 2015. $72 \mathrm{p}$. https://ehlm.unece.org/pages/viewpage. action?pageId=22741054 (In Russian)

6. Implementation plan: Strategic framework for adaptation to climate change in the Dniester basin. Zoï Environment Network, 2017. 76 p. http://www.zoinet.org/web/sites/default/ files/publications/Dniester-web.pdf. (In Russian).

7. Shtyasnyy P., Lapin M., Balabukh V. Adaptatsiya do zminy klimatu [Adapting to climate change]. Carpathian Institute of Development; Agency for the Promotion of the Sustainable Development of the Carpathian Region "FORZA". 2015. $\quad 88 \mathrm{p} . \quad$ http://www.forza.org.ua/sites/default/files/ global_climate_changes_training_manual_ua_screen_final.pdf

8. Kyyivs'ka mis'ka stratehiya. Poperedzhennya tá adaptatsiya do zminy klimatu: proekt. [Kiev city strategy. Preventing and adaptation to climate change: project]. The Taras Shevchenko university of Kyiv. 2013.188 p.

9. Balabukh V. O., Zhyla S. M., Orlov O. O., Yaremchenko O. A Vrazlyvi ekosystemy Polis'koho pryrodnoho 
zapovidnyka ta yoho okolyts' v umovakh hlobal'noho poteplinnya: problemy ta shlyakhy vyrishennya [Vulnerable ecosystems Polissya Nature Reserve and its surroundings in terms of global warming: Problems and ways of solution]. Kyiv: Publ. TOV «NVP Interservis», 2013. 92 p.

10. Otsinka vplyvu klimatychnykh zmin na haluzi ekonomiky Ukrayiny [Estimation of climate change impact on Ukrainian economy]. Odessa: Ekolohiya, 2011. 694 p. (Eds: S. M. Stepanenko, A. M. Polevoy).
11. Klimatychni zminy ta yikh vplyv na sfery ekonomiky Ukrayiny [Climate change and its impact on Ukrainian economy]. Odessa: Publ "TES”, 2015. 518 p. (Eds: S. M. Stepanenko, A. M. Polevoy).

12. Coastal Lagoons in Europe. Integrated Water Resource Management. London: IWA Publishing, 2015. 227p. (Eds: Ana I. Lillebø, Per Stålnacke, Geoffrey D. Gooch).

\title{
PROBLEMS AND PROSPECTS OF CLIMATOLOGY DEVELOPMENT IN UKRAINE
}

\author{
V. Balabukh ${ }^{1}$, Phd, \\ V. Khokhlov' ${ }^{2}$, prof.
}

${ }^{1}$ Ukrainian Hydrometeorological Institute, 37 Nauky Av., 03028 Kyiv, Ukraine, Balabukh@uhmi.org.ua ${ }^{2}$ Odessa State Environmental University, 15 Lvivska St., 65016 Odessa, Ukraine, khokhlovv@odeku.edu.ua

The article analyzes the current state of climatology in Ukraine, the problems and prospects for its development. It is shown that although Ukraine the signed the Paris Agreement and this fact is very important for the development of modern climatology, Ukraine's state policy on climate change has a fragmented character and is currently considered exclusively as a component of environmental policy. The lack of systems approach to the problem of climate change makes it impossible to make management decisions on actions for climate change adaptation and mitigation at the scale of whole economy of Ukraine. At the same time, the new tasks, which are due to the expediency of ratification by Ukraine of the Paris Agreement and the further implementation of its provisions, require the development of a coherent and consistent state policy on climate change.

The main scientific directions of the development of climate services in Ukraine are presented in accordance with the Global Framework for Climate Services. The main tasks for each element of climate services - a platform for interaction with users, an information system for climate services, observing and monitoring systems, capacity development - are outlined for Ukraine, problems are indicated and prospective directions of development are proposed.

Keywords: Climatology, Climate Services, Climate Change.

\section{ПРОБЛЕМЫ И ПЕРСПЕКТИВЫ РАЗВИТИЯ КЛИМАТОЛОГИИ В УКРАИНЕ}

\author{
В.А. Балабух ${ }^{1}$, канд. геогр. наук, с.н.с., \\ В.Н.Хохлов ${ }^{2}$, д-р. геогр. наук, проф. \\ ${ }^{I}$ Украинский гидрометеорологический институт, пр. Науки 37, 03028, Киев, Украина, Balabukh@uhmi.org.ua \\ 2 Одесский государственный экологический университет, ул. Львовская, 15, 65016, Одесса, Украина, \\ khokhlovv@odeku.edu.ua
}

В статье анализируется современное состояние климатологии в Украине, проблемы и перспективы ее развития. Представлены основные научные направления развития климатического обслуживания в Украине в соответствии с Глобальной рамочной основой для климатического обслуживания. Для каждого элемента климатического обслуживания: платформы взаимодействия с пользователями, информационной системы климатического обслуживания, наблюдения и мониторинга, развития потенциала выделены главные задачи для Украины, указаны проблемы и предложены перспективные направления развития.

Ключевые слова: климатология, климатическое обслуживание, изменение климата. 